\title{
Role-playing models in the vocational education of future agribusiness experts
}

\author{
Svetlana Bylkova $^{1,{ }^{*}}$ Elena Chubova ${ }^{1}$ \\ ${ }^{1}$ Don State Technical University, 1, Gagarin square, 344003, Rostov-on-Don, Russia
}

\begin{abstract}
The authors draw attention to the interconnection between job prestige and the general educational and professional development of future experts. In elaboration of the ideas of foreign researchers focused on humanitarian technologies in education, the authors highlight the significance of stimulating various personality processes: self-education, self-improvement, introspection, self-understanding, and personal growth. The paper objective is to show how global experience is transferred to the vocational education environment and applied in the student audience participating in business simulation games focused on the changing society with its new challenges. The authors prove that the development of communication skills, organizational abilities, the formation of the experience of finding likeminded people when solving production and job tasks, is provided by the balance of simulation and game models that reflect social and subject contexts. Business simulation games help to reinforce basic competencies in the sphere of business communication and to assess the degree of their development, to draw attention to the analysis of errors and communicative failures that arise in communication at production site, to focus on the specifics of barriers to success, and on the techniques that increase the business communication efficiency.
\end{abstract}

\section{Introduction}

The Russian agribusiness is badly in need of highly qualified employees and specialists of common professions. The employee pool of university graduates may be efficiently utilized not only through enhancing recognition of employment in the agricultural sector, but also through improving agricultural HR structure, enhancing the level of general and professional education. Thus, in our opinion, the lack of specialists is first of all related with the labor pool issues. Creating the labor pool is one of the demanded areas of staffing that implies the system of efforts related with training the senior executives and enhancing their qualification. Ten years ago, different farm businesses had about thirty thousand vacancies for senior executive positions and agricultural specialists. Therefore, the problem statement of our research is based on the fact that performance of both small farms and large businesses to a greater extent depends on the human capital, the workforce capacity of the enterprise, the ability to manage human resources, and to ensure functioning and development of the management system. The modern Russian agribusiness is committed to

\footnotetext{
*Corresponding author: svetbyl7592@rambler.ru
} 
overcoming the issue of shaping labor pools intended to augment the technology and knowledge potential of the state. At this stage of the social development, the enterprise workforce, the human resources are seen by HR specialists as the strategic reserve underlying development of both enterprises and national industries and corporations, sustainability of the country, holding the leading positions in the world of competition. Training of new employees implies the well-orchestrated educative process, providing students with the up-to-date laws and guidelines database and practical skills to be further used in the chosen area of production.

Humanization of education, as the scientific problem, is caused by the critical needs of the educative practice. Ever more often specialists emphasize that the modern education crisis arises out of the intrinsic causes because of the imperfection of the programme related with the loss of the conceptual meanings for the person's education. Different studies record aggravation of personal qualities, decline of people's moral stability, survivability, creativity and cultural management. That is why the humanitarian paradigm is oriented to identifying and unleashing all capabilities of the student.

Foreign researchers focused on humanitarian technologies in education highlight the importance of fostering diverse personality-based processes: self-education, selfimprovement, self-assessment, self-study, self-understanding, creativity and self-perfection. High efficiency of such processes can be reached with learning through play technologies. The foundations of different capabilities of play-based teaching methods and their application in education practice are reveled in works of Leutz G.A., K. Gross , K.Cailios, M. Rowe, TA Fay, E. Barz etc. The researchers have developed the sociological approach to the play, have recorded efficient impact of play-based methods on different personal qualities and extension of the emotional palette of the play participants that have found themselves in the sense-bearing stretch of the simulated reality. The end of the 20th century saw issue of the works by B. Damm, H. Petzold devoted to socialization of a personality, education and upbringing of the young generation using different play-based technologies, socio-dramatic playing and trainings. M. Müller [8], a German researcher, paid attention to the upbringing potential of the role playing paying special attention to the recovery of the inner world of a young person and his / her social role through the play. R. Schaller described role playing capabilities as the way of revealing the personality potential of its participants [5]. The monograph by N.M. Glukhenkaya presents research insights into the corporate HR management system based on the scientific method that implies active utilization of all components of the research methodology.

However, most authors share their experience paying attention to younger schoolchildren and teenagers. The purpose of our research is to show how the worldwide experience may be transferred to the vocational education environment and applied to another age category of the play participants.

In the world practice, the educative process features the combination of the internationalization and mutual impact of the national education models. The new Russian education model is intended to include HR training components known in the world practice in its contents, and to implement the deliverables of the advanced Russian innovations. The subsystem of HR system includes adaptation of personnel, enterprise HR policy, personnel training and other areas. In connection with this, various communicationcentered technologies oriented to the dynamically changing society with its new challenges become of paramount importance for development of future professionals. In this context, the management technologies designed to simplify the complicated work and free up time for employees' creativity come to the forefront.

No doubt, the management technologies are humanitarian technologies; their analysis in the context of training modern agribusiness specialists evidences that recent graduates often find themselves in the situation, when they are not (sufficiently) aware of the approaches to 
solving professional tasks, the tasks of continuous professional training. Failure to know these opportunities leads to non-adequate, mistaken assessment and choice of the tools the specialist needs, and therefore, the inability to use them efficiently. Thus, development of the competences of future workforce in the context of toughening expectations to professional criteria becomes the primary goal of the educative process.

Since today one of the main requirements is creating the efficiently running management system, equipping the students with the socio-humanistic toolkit, teaching them how to work with people become one of the most important tasks in the higher education process. And this cannot be done without knowledge of the communication theory, linguistics, communication studies, social and psychological studies, records management, philosophy, gerontology, economics and even educational science. Thus, these technologies are directly related with the communicative intersubjective environment. To navigate through it, one needs the set of special skills and knowledge that can be successfully developed during business games.

A business game is a form of symbolic context-oriented teaching that features specific learning and working characteristics allowing to simulate both social and professional relations of employees in the dedicated production field and actual production processes in the classroom. The modern educational science also treats the business game as the active teaching technique. In terms of psychology and educational science, main goals of the business game include forming and developing communication competences, acquiring the team work experience, career motivation, moral and ethical standards maintained across the university, production collective and the country as a whole.

A business game as the method of solving production / research and training tasks is intended to shape students' soft and hard skills and promote development of future professionals through its educative impact. That is why, the business game contents are based on the contents of taught subjects and reflect requirements of the professional field of activities as the set of general cultural and professional competences.

The educative practice of the Don State Technical University, through such academic subjects as Business Communications, Standard of Speech and Business Relations, FieldSpecific Linguistic Communication in Russian, uses business game as the efficient tool of simulating the "targeted" communication processes and search for the best options of the organizational development of future stakeholders of the research, development and production processes. The first two academic subjects are taught to the Bachelor's degree recipients, while the third and the fourth one - to the Master's degree programme students. This is accounted for by the objective necessity, since Bachelor's degree students acquire general knowledge, while Master's degree students get professional education.

Treating the business game contents as the artificially simulated production situation, we proceed from the requirements put forward by the professional community to agribusiness workforce. This field of operations uses work of various specialists majoring in: agriculture, forestry and fish management, veterinary science and zootechnics, economics and business management, industrial environment studies and biotechnology, technosphere safety and environmental engineering, applied geology, geodesy, oil and gas studies, psychology and others. In spite of the wide range of labor functions outlined in the professional standards for training of the agribusiness specialists, one can trace general features in the contents of the consolidated labor functions: professionals in this field of activities are supposed to correctly build relations in the work team using the most efficient tactics ensuring the labor tasks are solved; possess management skills, knowledge about accumulated data collection, processing, storage and transfer; have experience of documenting their deliverables in accordance with the established requirements. According to the analysis of the standards and guidelines that govern activities of the agribusiness 
specialists, the society sets high requirements to them emphasizing importance of their general cultural and professional competences.

High efficiency manifested through enhanced sense of self-worth and career ambitions of the students; shaping the experience of finding like-minders committed to resolve production and professional tasks is delivered by the reasonable combination of the simulation and play-based models reflecting the social and discipline-oriented contexts driving development of soft and hard skills. In our practice, we prefer the play-based model, which is undoubtedly related with the specific features of the subjects we lecture on. It is this model that best reflects all kinds of social relations, and therefore it is most suitable for drilling communication strategies and tactics that proved their efficiency in professional relations and serve mainly for the needs of business: those of actual communications, challenges, self-presentation, giving example and speech testing. Maneuverability of business communications is reached through hierarchy of the principles of social communications, with the principles of variability and ability to avoid conflicts on the top of the scale.

Now, let us mention the methods frequently used in the educative process when studying Business Communications, Standard of Speech and Business Relations, FieldSpecific Linguistic Communication in Russian that to a greater or lesser extent accompany or underlie the business game.

Thus, to understand the need to be able to act in different company's business areas, the workplace change method is used during classes that helps acquire and accumulate knowledge and skills due to regular change of the roles in the business situation simulated in the game; in real life, it corresponds to change of the job position.

\section{Research methods}

One of the most efficient methods the enterprise HR training system may offer is the buddy system. In the classroom environment, the role of the mentor is played by either a teacher, or an invited specialist, or a student, who prepared to play this role.

Before the cycle of business games, each of which pursues a certain aim, the teachers carry out diagnostics of abilities and potential personal capabilities of the students using the questionnaire that enables identifying communicative and managerial abilities (CMA). Speaking about the set of HR potential both for agribusiness and any other branches of human activities, these are basic abilities, since they are oriented to development of the social potential, including communication skills required for efficient socialization. It is the communication potential that helps shape such qualities as social perception, empathy, introspection and interest in people that are so demanded in the areas related with leadership and communications. The managerial abilities manifested through non-reliance in decision-making, leadership in communication and planning of the professional and research activities is of great importance as well.

Table 1. Findings of the Communicative and Managerial Abilities Diagnostics in the Beginning of the Educational Programme.

\begin{tabular}{|c|c|c|c|c|c|}
\hline Year & $\begin{array}{c}\text { Number of } \\
\text { participants }\end{array}$ & $\begin{array}{c}\text { Communicative } \\
\text { abilities score }\end{array}$ & $\begin{array}{c}\text { \% of the total } \\
\text { number of } \\
\text { participants / } \\
\text { number of } \\
\text { people }\end{array}$ & $\begin{array}{c}\text { Managerial } \\
\text { abilities } \\
\text { score }\end{array}$ & $\begin{array}{c}\text { \% of the total } \\
\text { number of } \\
\text { participants / } \\
\text { number of } \\
\text { people }\end{array}$ \\
\hline \multirow{2}{*}{$\begin{array}{c}2017- \\
2018\end{array}$} & \multirow{3}{*}{317} & 1 & $28 / 88$ & 1 & $40 / 127$ \\
\cline { 2 - 5 } & & 2 & $35 / 111$ & 2 & $30 / 95$ \\
\cline { 2 - 5 } & & $22 / 70$ & 3 & $18 / 57$ \\
\hline
\end{tabular}




\begin{tabular}{|c|c|c|c|c|c|}
\hline & & 5 & 0 & 5 & 0 \\
\hline \multirow{5}{*}{$\begin{array}{c}2018- \\
2019\end{array}$} & \multirow{5}{*}{322} & 1 & $24 / 77$ & 1 & $38 / 123$ \\
\hline & & 2 & $18 / 58$ & 2 & $10 / 32$ \\
\hline & & 3 & $28 / 90$ & 3 & $24 / 77$ \\
\hline & & 4 & $25 / 81$ & 4 & $20 / 64$ \\
\hline & & 5 & $5 / 16$ & 5 & $8 / 26$ \\
\hline \multirow{5}{*}{$\begin{array}{c}2019- \\
2020\end{array}$} & \multirow{5}{*}{460} & 1 & $18 / 83$ & 1 & $35 / 161$ \\
\hline & & 2 & $40 / 184$ & 2 & $35 / 161$ \\
\hline & & 3 & $20 / 92$ & 3 & $15 / 69$ \\
\hline & & 4 & $22 / 101$ & 4 & $15 / 69$ \\
\hline & & 5 & 0 & 5 & 0 \\
\hline
\end{tabular}

The scale of scores shows the level of manifesting communicative and managerial abilities from the lowest (1) to the highest (5). These findings serve as the starting point for building the communicative competence strategy related with rationalization and enhanced efficiency of the team management mechanism, harmonization of professional and interpersonal dialogue chosen as the preferred form of communications and resolving professional tasks, and with developing the versatile personality.

In the context of play-based teaching method, the role of the teacher is transformed from that of the knowledge broadcaster into the tutor and consultant. This change of the teacher's role facilitates enhanced engagement of students in the educative event, drives development of students' responsibility for the decisions they make and the team interaction strategies they choose.

Thus, with this change of the responsibility vector we can speak of efficiency of playbased teaching methods intended to shape certain managerial skills of future leaders. These skills are developed at different stages of the business game: at the pre-arranged (in case students are involved in the preparation) and onstage units and the critics and introspection units. The teacher's attention is focused on shaping the game motivation and maintaining it throughout the educative game session, on creating the competition dynamics for interpersonal relations.

For the purpose of the set goal and related tasks, an experienced teacher forecasts the risk situations, possible difficulties that can arise at any stage of the business game:

The 1st stage. Before the play-based process begins, the teams are formed within the student group in order to exclude long discussions about the way the roles should be distributed between the participants. At this stage, the main task of the teacher is to explain the rules of the game and dependence of the outcome on exact fulfillment of the rules.

The 2nd stage. To avoid transfer of personal relations into the play-based situation, the teacher explains conditional character of the game, and, if required, redistributes the roles between play-based communication members.

The 3rd stage. The final part of the session is devoted to summarizing and introspection. Its goal is to maximize efficiency of the feedback using all forms of surveys and questionnaires. The teacher initiates discussion of the business game engaging all participants of the play-based interaction.

Relying on the obtained findings, teachers choose forms of business communications preferred for a certain student group (business correspondence and presentation, telephone negotiations and discussions, business meeting and business negotiations) to select the required scenarios of business games. The business games that are used most frequently can be grouped into imitation, operations business games, on the one hand, and role playing games, on the other hand.

The first category includes business games, trainings, discussion seminars etc.; the second category, also called non-play, includes brainstorming, resolving case problems etc. 
In the course of vocational training of future professionals, we prefer business games, business trainings, algorithm-based training, simulation of case problems, and project learning that feature interactivity and creativity.

Business games of the first group are intended to imitate operations of the enterprise or one of its departments. The teaching session scenario consists of the event canvas, structure description and simulative processes and objects. The need to develop the generalized labor function skills underlies operations-based business games. Role playing is the logical extension of modifications of the above games - the game, during which tactics of behavior, actions, fulfilling functions and obligations of a certain job position are drilled.

The business game as a form of practical sessions is centered on development and improvement of communicative and managerial skills in the context of continuously changing external and internal conditions of the environment in order to obtain deeper knowledge of the laws of planning and managing the interaction as part of the enterprise system.

Development of business games is directly related with the role playing paradigm and is based on the psychological research devoted to team work efficiency and aimed to enhance the educative motivation and engagement. The business game is the process of stage-bystage formation of mental efforts and transfer of theoretical knowledge and skills in the field-specific professional activities. Psychologists and education professionals have repeatedly emphasized that playing is a great tool of simulation of new conditions of professional activities both at the notion and action level, since it opens wide opportunities to simulate different aspects of the social interaction and creativity. The advantages of the play-based simulation include wide choices of the contents components, potential teaching methods, varying number of participants of the game-based learning session, strategies of the speech communications, variability of the decisions made by the participants. All the above opens new educative possibilities.

Besides, the business game as one of the interactive educative methods is preferable as compared to the traditional teaching methods for a number of reasons. First, it allows to mitigate the antagonism between the abstract character of the subject and the actual character of professional activities, consistency of the employed knowledge and its reference to different subject areas. Second, it acts as the powerful booster of the social interaction and enhancement of professional communications through drilling the feedback skills and getting information filled in with the new content. And, of course, it facilitates development of introspection processes related with analysis of the obtained result.

High efficiency of the business game is reached through the post-game group analysis. Acting as the speaker, the teaching professional ensures the analysis is multi-faceted offering the participating students to discuss actions of the players, comment on the decisions they made, connections built between the actions, decisions they made and the tactics they have employed to implement these decisions and follow-up of the communications-based interaction. Much attention is also paid to the awareness of difference between expectations and personal needs the business game players may have.

Table 2. Findings of the Communicative and Managerial Abilities Diagnostics after Taking Part in the Cycle of Business Games Included in the Educational Process.

\begin{tabular}{|c|c|c|c|c|c|}
\hline Year & $\begin{array}{c}\text { Number of } \\
\text { participants }\end{array}$ & $\begin{array}{c}\text { Communicative } \\
\text { abilities score }\end{array}$ & $\begin{array}{c}\text { \% of the total } \\
\text { number of } \\
\text { participants / } \\
\text { number of people }\end{array}$ & $\begin{array}{c}\text { Managerial } \\
\text { abilities } \\
\text { score }\end{array}$ & $\begin{array}{c}\text { \% of the total } \\
\text { number of } \\
\text { participants / } \\
\text { number of } \\
\text { people }\end{array}$ \\
\hline 2017 & 317 & 1 & $19 / 60$ & 1 & $31 / 97$ \\
\hline- & & 2 & $31 / 100$ & 2 & $30 / 95$ \\
\cline { 2 - 6 } 2018 & & 3 & $25 / 78$ & 3 & $17 / 55$ \\
\hline
\end{tabular}




\begin{tabular}{|c|c|c|c|c|c|}
\hline & & 4 & $23 / 73$ & 4 & $20 / 64$ \\
\cline { 3 - 6 } & & 5 & $2 / 6$ & 5 & $2 / 6$ \\
\hline 2018 & 322 & 1 & $18 / 60$ & 1 & $28 / 90$ \\
\hline \multirow{2}{*}{2019} & & 2 & $17 / 59$ & 2 & $11 / 34$ \\
\cline { 3 - 6 } & & 3 & $30 / 92$ & 3 & $26 / 84$ \\
\cline { 3 - 6 } & & 4 & $28 / 90$ & 4 & $24 / 78$ \\
\cline { 3 - 6 } & & 5 & $7 / 21$ & 5 & $11 / 36$ \\
\hline 2019 & 460 & 1 & $14 / 65$ & 1 & $32 / 149$ \\
-2020 & & 2 & $37 / 170$ & 2 & $31 / 146$ \\
\cline { 3 - 6 } & & 3 & $22 / 100$ & 3 & $17 / 76$ \\
\cline { 3 - 6 } & & 4 & $24 / 110$ & 4 & $18 / 80$ \\
\cline { 3 - 6 } & & 5 & $3 / 15$ & 5 & $2 / 9$ \\
\hline
\end{tabular}

The information presented in the table is self-explanatory. We have managed to adjust personal qualities of the students directly related with communications and management through engaging students in the learner-centered educative process that includes project and play-based teaching technologies, interactive methods, and problem-based learning.

Therefore, the number of students eager to communicate without restricting the range of social contacts, are able to plan their activities, stand the ground, has increased for $3 \%$ (2017-2018 academic years). However, since the personal changes are not consistent yet, students of this group need further work aimed to strengthen and consolidate the qualities they have shaped.

Due to the business game cycle, the indicator of "ratees referred to the group featuring high level of communicative and managerial abilities" has also improved. Thus, the number of students that can make friends easily by continuously extending their social circle; show initiative in public life and are ready to assume responsibility for the decisions they made by themselves increased from 48 up to 73 (2017 - 2018 academic years), from 81 up to 90 (2018 - 2019 academic years ), from 101 up to 110 (2019-2020 academic years ).

It's worth noting that in 2017 - 2018, 2019 - 2020 academic years, there were no students having high level of communicative and managerial abilities, while in $2018-2019$ academic year there were $5 \%$ of students featuring communicative abilities and $8 \%$ of students featuring managerial abilities of the total number of hearers of the Culture of Oral and Written Speech, the Field-Specific Linguistic Communication in Russian. However, due to efficient learning sessions that included trainings and business games the number of students was increased up to $2 \% / 2 \%$ in 2017 - 2018 academic year, up to $7 \% / 11 \%$ in 2018 - 2019 academic year and up to $3 \%$ / 2\% in 2019 - 2020 academic year. Let's highlight personal qualities of these students: feeling the need in communications and management activities, they are easily adaptive in the work team assessing potential of every group member adequately, feel comfortable in the work team; they can stand their ground, show initiative and persistent in the activities that are attractive for them; besides, they seek the activities satisfying their need in communications and management.

Let us mention that one of the conditions of efficient utilization of the development potential of the business game is differentiation and interrelation of the roles taking into account personal peculiarities of the students, and well-managed individual and group goals. In this context, students acquire skills of behavior expected in different business scenarios: interviews, meetings, negotiations, self-presentation, presentation of their production or research deliverables.

\section{Conclusions}

Business games help to strengthen the main communicative competences and assess the extent, to which they are shaped, to highlight the analysis of mistakes and communication 
failures arising in the course of communications at the enterprise, to pay attention to the specific features of the bar to success and the techniques than enhance the business communication efficiency. However, this teaching approach has a number of disadvantages, of which the most important is complicated preparations accounted for by the lack of formalized criteria that allow to give the unbiased assessment in line with the real-life situations; and the need to independently develop the business game algorithm for a certain student group.

Thus, the promising vector of the innovation development in education and training of agribusiness specialists looks forward to the humanitarian technologies, since they enable young specialists to maximize the potential of the professional competences demanded by the modern society. However humanization of the educative process implies transformation of the students into self-developing personalities that assume responsibility for the outcome of shaping their professional identity and are interested in self-education implying comprehensive development of intelligence and emotional sphere, adoption of the social and cultural values of the education and upbringing closely related with life and development perspectives of society.

The efficiency of the business game as the form of the symbolic context-oriented teaching is manifested through enhanced sense of self-worth and career ambitions of the students; acquiring the experience of finding like-minders committed to resolve production and professional tasks, and, ultimately, the experience of reaching accord of the social and personal expectations.

\section{References}

1. E.J. Austin, M.M. O’Donnell, Personality and Individual Differences 55(7), 834-839 (2013)

2. T. Bourke, R. Sargisson, American Journal of Play 6(3), 370-391 (2014)

3. J.A. Cannon-Bowers, C. Bowers, APA handbook of industrial and organizational psychology Vol. 1. Building and developing the organization (American Psychological Association, Washington, DC, 2010)

4. A.W. Woolley, Science 330(6004), 686-688 (2010)

5. A. Krapp, M. Prenzel, International Journal of Science Education 33(1), 27-50 (2011)

6. J.G. Mehring, An exploratory study of the lived experiences of japanese undergraduate EFL students in the flipped class room (Pepperdine University, ProQuest Dissertations \& Theses Global, 2014) http://search.proquest.com/ docview/1652925200? accountid=35419

7. T.W. Moore, Educational Theory: An Introduction (Routledge, N.Y., 2012)

8. A. Januszewski, M. Molenda, Educational Technology: a Definition with Commentary (Routledge, N.Y., 2013)

9. A. Pentland, Harward Business Review. Harvard: Harvard Business School Pub, 62 70 (2012)

10. R. Pekrun, Educational Practices 24, 6-29 http://citeseerx.ist.psu.edu/viewdoc/download?

11. K.J. Pugh, Educational Psychologist 46(2), 107-121 (2011)

12. A.J. Romiszowski, Designing Instructional Systems: Decision Making in Course Planning and Curriculum Design (Routledge, N.Y., 2016)

13. A. Rudawska, M. Szarek, Ementor 3(55), 12-21 (2014) 
14. D.S.Jr. Smith, The predictive relationship between cultural identity, value orientation, acculturation and the cross.cul. tural student's academic motivation in the international school setting (Liberty University, ProQuest Dissertations \& Theses Global, 2015) http://search.proquest.com/docview/1672691265? accoun6 tid=35419

15. D. Wheeler, J.K. Stoller, Canadian Journal of Respiratory Therapy 47(1), 6-11 (2011) 